\title{
The New Development Of Subject Of International Law
}

\author{
Supardan Mansyur ${ }^{1}$ \\ Faculty of Law Mataram University \\ St. Majapahit No. 62 Mataram 83125, Telp. (0370), 633035, Fax. 626954 \\ Email:supardan@gmail.com \\ Zunnuraeni $^{2}$ \\ Faculty of Law Mataram University \\ St. Majapahit No. 62 Mataram 83125, Telp. (0370), 633035, Fax. 626954 \\ Email: zunnuraeni@gmail.com
}

\begin{abstract}
Nowdays the status of subject of international law is one of the most controversies in international law, particularly in part of corporation (multinational entities) and non governmental organizations. Since the status of subject of international law gives entities rights and duties under international law, it is important to find out the new development in the subject of international law. The issue in this article is what is the new development on the establishment and recognition of subject of international law?. To solve the issue, this article using normative reseach with conceptual approach and historical approach. The conclusion withdrown is that The new development in the subject of international law is the debate on the establishment and recognition of corporations and Non Governmental Organization as subject of international law. The view that corporation and NGO should established as subject of international law is based on the important role those entities has played in international plane. However, regardless the important role they play, they can not considered as the subject of international law since the lack recognition from international community.
\end{abstract}

Keywords: subject; international law; new; development.

\section{INTRODUCTION}

Legal personality giving an entity, whether individual or company rights and duties putting them as a subject of law is very importance. As the subject of law the individual may prosecute or be prosecuted for assault and a company can sue for breach of contract. They may do this because the law recognizes them as 'legal persons' possessing the capacity to have and to maintain certain rights, and being subject to perform specific duties. ${ }^{3}$

A subject of law in international is an entity, as decided by I.C.J in its decicion in the Reparaition for the injuris case, I.C.J Reports 1949, capable of possessing international rights

\footnotetext{
${ }^{1}$ Lecturer of Law Faculty of Mataram University

${ }^{2}$ Lecturer of Law Faculty of Mataram University Shaw,Malcolm N. International Law, http://jpkc.fudan.edu.cn/picture/article/460/05/ 56/944404884db8857880997b8500b1/694d8cb6-b013-42a3-837a-2298e170ed58.pdf. pdf, (acsessed 16 January 2017), p. 195.
} 
and duties and having the capacity to maintain its rights by bringing international claim. ${ }^{4}$ Right and justies here, means: firstley, rights and duties under interationat law, as a concequence those under other legal system not count; secondly; the rights and duties... must be strictly the legal rights and duties, and not only benefit and burden which a rule of internatonal law treaty may bring to any entity; and thirdly, the rights and duties bust be posses by or incumbent upon the subject concerned to who the law really intends them to be adrdressed. ${ }^{5}$ Traditional views considered that the only subject of international law are sovereign states; ${ }^{6}$ making them capacity to make claim in the international field against the breaches of international law, capasity to make treaties and other international binding agreement, and enjoy priveleges and immunities from national jurisdiction. ${ }^{7}$ According to Ian Brownlie, the indicia revered to the status as subject of law depend on the existence of the legal person, in other word based on customary law an entity having capability to posses rights and duties, and having these capacities given to it, is a legal person. ${ }^{8}$ For him, if the first condition cannot be fulfilled, an entity remains to have legal personality depend on the agreement or acquiescence of recognized legal persons and opposable on the international field only to those agreeing or acquiescence. ${ }^{9}$

This means that apart from the state having full rights and duties as the subject of international law, there are potentiality to recognize other entities as subject of international with the limited rights and duties. Mochtar Kusumaatmadja and Etty R. Agus, call the first as the full subject of international law. ${ }^{10}$ They refer to individual as an example of subject of international law with limited rights and duties. ${ }^{11}$ In addition to the subjects of international status may be obtained along side with the appearance international law; may be as the historical factors; or may be created law to fulfill the community need. ${ }^{12}$ The states are the only subject international existing together with the birth of international law, the Holy See is the example of the subject of international law as the historical factor, and the international organizations get the status of subjects of international because international law has been recognized them

\footnotetext{
${ }^{4}$ Brownlie, Ian (1979),Principle of Public International Law, third edition. Oxford, Clarendon Press, , p. 60.

5 Mohammed Bedjaoui, (General ed.),(1991), International Law, Achievement and Prospect, UNESCO Paris. Dodrecht/Boston London: Martinus Nijhof Publisher, ps. 25.

${ }^{6}$ Even Mochtar Kusumaatmadja stated that in the antiquity its governed the relations between the kings where these are rare and therefore can not be considered as the relations between the members of a nation community, in Mochtar Kusumaatmadja and Etty R Agus, (2013) Pengantar Hukum Internasional (Introduction to International Law). Bandung: Alumni, p. 6.

${ }^{7}$ Kaczoroswka, Alina (2002), Public International Law. London: Old Baily Press, p. 49.

${ }^{8}$ Brownlie, Ian (1979), Op.Cit., p. 60

${ }^{9}$ Ibid.

${ }^{10}$ Mochtar Kusumaatmadja and Etty R. Agus,(2013), Op.Cit., ps. 96-97.

${ }^{11}$ Ibid.

${ }^{12}$ Ibid.
} 
as such.

The adoption of individual as the subject of international law marks the beginning of the subject of international law development, followed the other subjects risen in the international law arena as stated by Mohammed Bedjaoui stated that: ${ }^{13}$

Fundamentally, international law remains to this day a law which discipline the jurisdiction of in the relations between them. But it is clear that it has begun to take an interast in the conduct of the states toward individuals. this sift, which has not come about the linear fashion, gained in imporatance whwn even garadually gave rise to the necceccity of protecting the personand goods of foreigners, then of nationals, then of groups such as minorities whithin a state, then of human communities constituting the people and then of all individuals and collective human rights. The active principle of this evolution was undeniably the right of people to self-determintation. It was gradually dikcovered - with some surprise that it had taken so long - that the state which had for long been more exclusive and sacrosanct subject of internasional law.

In the past we have witnessed many development on the subject of internationsl law. In addion to individuals, group of minorities as stated by Mohammed Bedjaoui, the Holy See, The Order of Malta and the papal Bull "Pie postulatio voluntatis" of $1113,{ }^{14}$ International Commitee of the Red Cross, International Organization, insutgent, and belligerent. ${ }^{15}$ They can be said as the actors in international law, and most of them are non state.

Andrew Clapham as quoted by Mohammad H. Zarei, and Azar Safari states that "the concept of non-state actors is generally understood as including any entity that is not actually a state, often used to refer to armed groups, terrorists, civil society, religious groups or corporations". ${ }^{16}$ Article 6 of the COTONOU Agreement extend this concept by stating the actors of cooperation will include: a: State (local, national and regional), b: Non-State: - Private Sector; - Economic and social partners, including trade union organizations; - Civil society in all its forms according to national characteristics. ${ }^{17}$

However as Malcolm N. Shaw reminded us to determined the subject of legal status an

\footnotetext{
${ }^{13}$ Mohammed Bedjaoui, Op.Cit., ps. 11-12.

${ }^{14}$ See Bo J Theutenberg, The Holy See, the Order of Malta and International Law, http://www.theutenberg.se/pdf/the_holy_see_the_order_of_malta_and_internationa, (accessed 6 January 2017).

${ }^{15}$ See Kusumaatmadja, and Agus, Op. Cit., ps.95-112.

${ }^{16}$ See Mohammad H. Zarei, Azar Safari, The Status of Non-State Actors under the International Rule of Law: A Search for Global Justice, http://www.culturaldiplomacy.org/academy/content/pdf/participant-papers/2014-04-lhrs/ Dr_Zarei_and_Azar_Safari_-_The_Status_of_Non-State_Actors_under_the _International_Rule_of_LawA_Search_for_Global_Justice.pdf, (accessed 9 January 2017), p. 3. ${ }^{17}$ Ibid.
} 
entity in international law because many factors must be considered. He states that:

... a range of factors needs to be carefully examined before it can be determined whether an entity has international personality and, if so, what rights, duties and competences apply in the particular case. Personality is a relative phenomenon varying with the circumstances. One of the distinguishing characteristics of contemporary international law has been the wide range of participants. These include states, international organizations, regional organizations, nongovernmental organizations, public companies, private companies and individuals. To these may be added groups engaging in international terrorism. Not all such entities will constitute legal persons, although they may act with some degree of influence upon the international plane. International personality is participation plus some form of community acceptance. The latter element will be dependent upon many different factors, including the type of personality under question. It may be manifested in many forms and may in certain cases be inferred from practice. It will also reflect a need. Particular branches of international law here a replaying a crucial role. Human rights law, the law relating to armed conflicts and international economic law are especially important in generating and reflecting increased participation and personality in international law. ${ }^{18}$

Today, it is recognized univerasally that the established subject of international law are state, International Commitee of the Red Cross, the Knight of Malta, Holy See, International Organization, individual, insurgent and belligerent. Certaintly the number of the subject of international law will be increased with the non state actors parallel to the develoment of international cummunity need and the law regulated them. However the concept of subject of international is not static. It is develop along with international society. Increasingly, there is a trend towards accepting private person, whether legal or natural, as having limited international personality for the purpose of carrying out limited category of transaction. ${ }^{19}$

Based on these fact may be identified issue, namely: what is the new developments on the establishment and recognition of subject of international law?

\section{RESEARCH METHOD}

To analyze the issue that will discussed in this article, it used normative study. This study only use literature as research data. Data collected by searching literature in different library as well as electronic literature with the internet. Approach used in this study are conceptual

\footnotetext{
${ }^{18}$ Shaw, op. cit., p. 196-197

${ }^{19}$ Kaczoroswka, Alina, Op.Cit., p. 49.
} 
approach and historical approach.

\section{ANALYSIS AND DISCUSSION}

\section{The Existing subject of international Law}

The status as subject of law, both in national or domestic law and international law status is very important. This status give them rights and duties to do or forbearance anything . They may do this because the law recognizes them as 'legal persons' possessing the capacity to have and to maintain certain rights, and being subject to perform specific duties.

The existing subjects of international law are those accepted as the subject international by the writers in international law today. They are state, International Organization, Holy See, Intdernational Committee of the Red Cross, individual, Insurgent and belligerent. ${ }^{20}$

\section{States}

States are classical subject of international since international law to be appeared, even now there is an assumption that international law, in essence, is interstate law. ${ }^{21}$ They have full right and duties in international law. The states with full rights and duties are referred to as sovereign states ${ }^{22}$ or independent states. ${ }^{23}$ Each state may called as a sovereign state if it has fulfilled some conditions as determined in Montevideo Convention, namely: (a) a permanent population; (b) a defined territory; (c) government; and (d) capacity to enter into relations with other states'. ${ }^{24}$

Those states having full duties and right in their status as unlimited international personality, ${ }^{25}$ together with international organization are called as the normal types of legal persons, ${ }^{26}$ the full subjects of Jnterntional Law.

Apart from the independent states, the dependent states likewise recognized as the subject of international law with limited rights and duties in international plane. They are political entities proximate to states (case of Danzig), condominia, Internationalized territory, agdencies of states (for-examples the Joint Cmmission set up under an agreement concerning boundries water between Canada an the United States in 1919, and the Former Commission of the Danube), Agencies of the Organizations (through constituent treaty may be created

\footnotetext{
${ }^{20}$ Kusumaatmadja and Agus, Op.Cit. ps. 95-112.

${ }^{21}$ Ibid..,ps. 98.

${ }^{22}$ Kackzorowska, Op.Cit., p. 49.

${ }^{23}$ See Bengt Broms, "States" in Bedjaoui, Op. Cit., p.47.

24 Malcolm N. Shaw, International Law, http://jpkc.fudan.edu.cn/picture/article/460/05/56/ 944404884db8857880997b8500b1/694d8cb6-b013-42a3-837a-2298e170ed58.pdf. pdf, (acsessed 5 january 2017). p. 198

${ }^{25}$ Kackzorowska, Op.Cit., p. 55.

${ }^{26}$ Browlie, Op.Cit., p. 61.
} 
subsidiary organs having a significant amount of independent and invested with considerable administrative, rule making with judicial powers without themselves obtaining a distinct legal personality), non self governing peoples, and states with statunascendi, ${ }^{27}$ mandate and trusteeship territories. ${ }^{28}$

\section{International Organizations}

As the subject of international law, the rights and duties of international organizations like United Nations and International Labor Organization are determined in International Conventions applicable to their statutes. ${ }^{29}$ Advisory Opinion of the ICJ in the Reparation for Injuries Suffered in the Service of the United Nations (1949), ICJ Rep 1974. This case related to the assassination of Count Folk Berdotte a Swedish National, the UN Chip Negotiator, and a Frenchman, Colonel Andre Serot an observer, by Jewish terrorist Organization while an official mission ......clarified and strengthen their status as the subject of international law. ${ }^{30}$ They, like the states, are the normal subjects of international law, and therefore have rights and duties in international plane completely.

\section{Other subjects of international law}

As we have explained, only the states and international organizations being the normal subjects of international with the full rights and duties. This means that other subject of international law including Knight of Malta, Holy See, International Committee of the Red Cross have the limited rights and duties under international law.

\section{The subject of international law in controversies}

\section{Corporation as the potential subject of international law}

In realities there are municipal corporations, both private and public, involve economic activites in one or more states beyond their state under the law where they were "incorporated" or in which they have their economic seat. The individual corporation has resources even greater than those of the smaller states, and maybe get powerful diplomatic backing from governments. Such corporations may make agreements, including concession agreements, with foreign governments, and related to this, jurists have argued that this relations of states and foreign corporations should be treated on the international field, not as an aspect of the normal rules on the position of aliens and their assets on the territory of a state. In principle, corporations of municipal law have no international legal personality. Indeed, a concession or

${ }^{27}$ Brownlie, Op.Cit., ps. 63-67.

${ }^{28}$ Kackzorowska, Op.Cit., p. 63.

${ }^{29}$ Kusumaatmadja and Agus, Op.Cit, p. 101.

${ }^{30}$ Kackzorowska, Op.Cit., p. 64. 
contract between a state and a foreign corporation is not governed by the law of treaties but today it must be explained that it will not always be easy to distinguish corporations which are so closely controlled by governments as to be state agencies, with or without some degree of autonomy, and private corporations not sharing the international law capacity of a state. It will be clear that the conferment of separate personality by a particular national law is not necessarily conclusive of autonomy vis-a-vis the state for purposes of international law. Thus ownership of shares may give a state a controlling interest in a private law corporation'. 31

Important functions are performed today by bodies which have been grouped under the labels 'intergovernmental corporations of private law' and 'etablissements publics internationaux'. The point is that states may by treaty create legal persons the status of which is regulated by the national law of one or more of the parties. However, the treaty may contain obligations to create a privileged status within the national law or laws to which the corporation is subjected. The parties through their agreement may give certain immunities to the institution created and confer it various powers. It is given the independence from the national laws of the parties, then the body concerned may simply be a joint agency of the states involved, with delegated powers applicable to the international plane and with a privileged position vis-a-vis local law related to its activities. In addition to independence from national law, a considerable quantum of delegated powers and the existence of organs with autonomy indecision and rulemaking, then the body concerned has the characteristics of an international organization. It is when the institution created by treaty has a viability and special function which render the description 'joint agency' inappropriate, and yet has powers and privileges primarily within the national legal systems and jurisdictions of the various parties, that it calls for use of a special category. An example of intergovernmental enterprise of this kind is Eurofima, a company set up by a treaty involving fourteen states in 1955, with the object of improving the resources of railway rolling stock. The treaty established Eurofima as a corporation under Swiss law with modifications in that law provided for in the treaty. The parties agreed that they would recognize this (Swiss) private law status, as modified by the treaty, within their own legal systems. The corporation is international in function and the fourteen participating railway administrations provide the capital. The corporation is also given privileges on the international plane, including exemption from taxation in Switzerland, the state of domicile. However, useful as the category 'etablissements publics internationaux' may be, it is not an instrument of exact analysis, and

31 Nagoibaeva K Elidi.,et.all (Ed), (2012), Contemporary International Law, Material and Cases, Bishkek, Kyrgyzstan, Printing House “Alty Print” LLC, Op Cit. Ps. 77-78. 
does not represent a distinct species of legal person on the international plane. This type of arrangement is the product of a careful interlocking of the national and international legal orders on a treaty basis, and the nature of the product will vary considerably from case to case. ${ }^{32}$

The rise of national corporations both private and public with a broad range activities, and involving share horders crossing of the states boundries, known as intergovernmental orporations causing controversies related to their status as the subject of International law. ${ }^{33}$ This corporations together with Multinational Enterprises (MNEs) or Multinational Corpirations (MNCs)has involved in economic and business activities crossing the states. This change the corporation figure as enterprise located within the order of municipal law in which they based. ${ }^{34}$ The transnational character of modern corporatios has raised a question related to whether international should rules on corporate actors.In reality as has been indicated recently new sets of claims have arisen relating to the accountability and liability of corporations for acts that may infringe international law. Equally, calls for a transparent, stable, and predictable investment environment have given rise to specialized rules of international law that offer protection to the assets of corporate investors among others. ${ }^{35}$

Iman Handono, optimistically answered his questions on the possibility to force MNCs responsibility through international law instrument. For him, to force MNCs to apply these instruments, MNCs need to be actively as the parties in formulating, drafting, agreeing, signing and controlling their implementation, that will put them similar to the states. Then, those may be treated as the subject of international with the similar rights and responsibilities to the states if they fulfill three requirements as stated by Brownlie, namely: (1) there are capacity to bring the claims related to the violation of international law; (2) there are capacity to conclude international treaties; and (3) there are privilege and immunities inherence to the natural jurisdiction. ${ }^{36}$

Similar to Handono, VAUGHAN LOWE insists the corporations capable to be treated

\footnotetext{
${ }^{32}$ Ibid. 78

${ }^{33}$ Ibid.

${ }^{34}$ Jan Wouters Anna-Luise Chané, MULTINATIONAL CORPORATIONS IN INTERNATIONAL LAW, Working Paper No. 129 - December 2013, https://ghum.kuleuven.be/ggs/publications/working_papers/new_series/wp121-130/wp129wouters-chane. pdf (accesed 6 January 2017).

${ }^{35}$ Working Paper No. 129 - December 2013 MULTINATIONAL CORPORATIONS IN INTERNATIONAL LAW, https://ghum.kuleuven.be/ggs/publications/working_papers/new_series/wp121-130/wp129-wouters-chane.pdf (accessed 6 January 2017), ps. 3-4.

${ }^{36}$ Iman Prihandono, "Status dan Tanggung Jawab Multi -National Companies (MNCs) dalam Hukum International ", Global \& Strategis, Th. II, No. 1, Januari-Juni 2008, hlm. 69-84, http://journal.unair.ac.id/download-fullpapers5\%20Status\%20MNC\%20-\%20final\%20edit\%20OK.pdf, (accesed 10 January 2017), p. 72.
} 
as the subject of international law. He explains that: ${ }^{37}$

.... in the WTO dispute settlement process and in the ITLOS, for example, the reality is that it is often the interests of specific companies that are the cases belli, as it were, and that it is the companies that effectively shape and control the character of the litigation. But the face behind the mask is a constant in international life, and in some ways not the most important aspect of this matter. More important are those circumstances in which companies are the overt actors within the international legal system. As far as their fundamental role within the system as participants in the making and development of international law is concerned, there are two mechanisms by which they exercise a direct and very significant influence. The first, already evident in the middle of the twentieth century, is through the making of agreements with States, governed (at least in part) by international law, under which the company has in the event of a breach of the agreement, the right to litigate against the State Party on a footing of judicial equality. A century ago, if a foreign investor was mistreated, its national State would bring an international claim against the alleged wrongdoing State. Under concession agreements, the foreign investor may bring such claims before a tribunal in its own name. The massive growth in bilateral investment treaties (BITs), which now number over 2,000, has consolidated this development by giving such a right to investors in the States Parties in general. Arbitrations arising from such agreements are conducted in a manner that is practically indistinguishable from inter-State arbitrations; and the resulting awards, in cases such as the great Libyan oil arbitrations of the 1970s, are commonly cited alongside inter-State awards as authorities on propositions of international law. The implication is obvious. If, for example in the course of US-Mexican claims concerning the treatment of the property of foreign nationals, claims are put forward and accepted by States, we say that the process - to the extent that it reflects an international consensus, at least - generates customary international law. Why should we not say so if the claim is made or accepted in the course of dealings between companies and States? The answer, it seems to me, is more a matter of taste than of logic. We might insist that it is only the acceptance of corporate claims by States, and not their making by corporations, that is legally relevant. We might say that the powers of corporations all derive ultimately from States,

${ }^{37}$ LOWE, VAUGHAN, CORPORATIONS AS INTERNATIONAL ACTORS AND INTERNATIONAL LAW MAKERS, https://eclass.uoa.gr/modules/document/file.php/LAW274/II.\%20\%CE\%97\%20\%CE\%B5\%CF\%80\%CE\%B9\%CF\%87\%CE \%B5\%CE\%AF\%CF\%81\%CE\%B7\%CF\%83\%CE\%B7\%20\%CF\%89\%CF\%82\%20\%CF\%85\%CF\%80\%CE\%BF\%CE\%BA

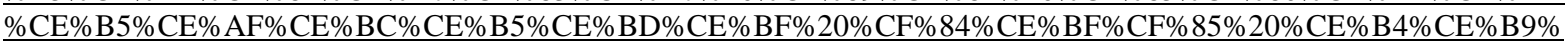
CE\%B5\%CE\%B8\%CE\%BD\%CE\%BF\%CF\%8D\%CF\%82\%20\%CE\%B4\%CE\%B9\%CE\%BA\%CE\%B1\%CE\%AF\%CE\%B F\%CF\%85/Lowe\%20-\%20Corporations\%20as\%20International\%20Actors\%20and\%20International\%20Law\%20Makers2.pdf (accesed 9 January 2017), ps 23-24. 
so that any authority their actions may have is the authority of the State. But there is no reason why we must adopt such an approach unless we are first committed to the view that it is the logical basis of a company's capacity and powers that is the relevant factor; and there is no more reason to be committed to that proposition than there is to be committed to, say, the social contract as the basis of political authority within a State. It is an existential leap or an article of faith; and one cannot ask whether it is correct but only ask whether it is useful. For my part, I do not think that any dogmatic position on the question whether corporations are "subjects" of international law or "international actors" is helpful. They have some characteristics in common with States, the archetypal subjects of international law, and some characteristics in common with human beings, the archetypal "objects" of international law; and they should be recognised as entities sui generis whose treatment, and the treatment of whose actions, in international law needs to be approached on a pragmatic, case-by-case, basis.

The facts that the states and large global corporations share similar characteristics empowering both to the status of actor, the large global corporations should be considered actors under international law. Both States and corporations enjoy control and power capable of causing severe harm through violations of international law. Moreover, the change that may be unpredicted in our world; globalization wherein large corporations maintain bases and operate in nations far from "home"; the partnering between those large corporations and various governments; the outsourcing of historically public governmental functions to private corporations and the increasing prominence of sovereigns acting in the private sphere, large global corporations and states should be treated similarly ${ }^{38}$.

Although, as indicated by the realities putting the large global corporations share similar characteristics empowering both to the status of actors, and, therefore, should be considered actors under international law, but without recognition from the international community those may not be considered as the subject of international Law. This is as noted by Karsten Newroot based on the view of international law schollars:

According to the currently still predominant view among international legal scholars, not all of the various different entities participating in contemporary international relations can be regarded as international legal persons, even if they may have some degree of influence on the international society. De facto participation is not equivalent to acting on the international

${ }^{38}$ SLAWOTSKY, JOEL The Global Corporation As International Law Actor in VIRGINIA JOURNAL OF INTERNATIONAL LAW DIGEST [Vol. 52:79, 2012, http://www.vjil.org/ assets/pdfs/vjilonline2/Slawotsky_Post_Production.pdf (accesed 9 January 2017), ps. 80. 
scene in legally relevant ways, and thus does not convey the status of a subject of international law. Rather, international legal personality requires some forms of community acceptance through the granting by states of rights and/or obligation under international law to the entity in question ${ }^{39}$

However, some commentators has call a different view with this traditional international law view. C Harding and C L Lim as noted by Sunniva Samdal have argued that international law needs to depart from the Westphalian model and rather ask which political actors shape the legal processes and how they do so in order to establish whether they are subjects of international law. ${ }^{40}$ Karten Newroot has proposed a new approach in order to established status of subject international law, particularly multinational corporation, as noted bellow:

In an economic as well as political sense, these non-state actors are among the most influential participants in the current international system, thereby being endowed with a considerable potential to positively contribute to, but also to frustrate the promotion and protection of global public goods. Thus, in light of the central aims pursued by the international legal order and because of the need of a close conformity of international law to the changing realities in the international system, a presumption - until today not rebutted by states and international organizations - arises in favour of multinational corporations being subject to international legal obligations to contribute to, inter alia, the promotion and protection of human rights, core labour and social standards as well as the environment. ${ }^{41}$

\section{Non Governmental Organization}

Non Governmental Organizations appear to international arena and be a subject discussion on their status in international law. Since their appearance these organization have the importance role because of their involvement in various activities both in national level and international level.

In international level they had actively given their contribution to foster treaties, promote the creation of new international organizations (IOs), and lobby in national capitals to get consent to stronger international rules. Even A decade ago, Antonio donini, writing about the United Nations, declared that "the Temple of States would be a rather dull place without

${ }^{39}$ Nowrot, Karsten, New Approcah to the International Legal Personality of Multinational Corporations toward a rebutable Presumption of Normative Responsibilities, http://www.esil-sedi.eu/sites/default/files/Nowrot.PDF, (acsessed 9 january 2017), p. 4.

40 Samdal, Sunniva, The Issue of legal Personality Within The Modern International Legal System. https://www.aber.ac.uk/en/media/departmental/lawcriminology/pdf/publications/auslcj2014/5---The-Issue-of-LegalPersonality-within-the-Modern-International-Legal-System.pdf, (accessed 9 January 2017)P. 7.

${ }^{41}$ Nowroot, Karsten, Op.Cit.,p. 25. 
nongovernmental organizations,"' that suitable to more general thesis: had NGOs never existed, international law would have a less vital role in human progress. ${ }^{42}$

Non Governmental Organizations in general have played the importance role in international arena, the same role even more has been played in the international plane. Because the role they played, is not surprising if many of the scholars propose them as the subject of international law. Their involvement in identifying with the language and purposes of international law giving them legitimacy in various activities and their expertise in actual economic, environmental, political, or social conditions, including states' compliance with their international commitment put them as the influence organizations. ${ }^{43}$

Indeed Non-governmental organizations often against policies of their governments or international communities and protest those policies, like what they did in the recent protests of anti-globalization activists in Seattle, Gothenburg, Porto Alegre, Davos, Genoa, and many other locations, putting them to be an integral part of the procedures and structures of global governance, they have positive cooperation with those governments and international community through direct involvement in designing policies and may shape political processes from inside the official arenas. They are, for-example significantly involved in the activities and performances of the intergovernmental organizations (IGOs), in advise U.N. commissions and committees regularly, working together with U.N. agencies and implementing projects for them, or assisting U.N. institutions and provide necessary information. ${ }^{44}$

In European Community, Non Governmental Organization got opportunity to be a legal person through their national law. The recognition of Non Governmental Organization as the subject of international law. This importance role is not play by the International Non Governmental Organizations only, but also by the Non Governmental Organizations in general.

Similar to the corporations, the impotent role playing in international law mainly in their involvement related to the producing of international law instrument including in interpreting them, the lack of recognition do not change their status to be the subject of international. It is

${ }^{42}$ Charnovitz, Steve "Nongovernmental Organizations And International Law", in The American Journal of International Law, Vol. 100, No. 2 (Apr., 2006), pp. 348-372 Published by: American Society of International Law, http://www.ivr.uzh.ch/dam/jcr:ffffffff-bd54-b312-0000-00007162452b/Text-18.pdf, (accessed 10 January 2017), p.348.

${ }^{43}$ Thomas, Daniel C. International NGOs, "State Sovereignty, and Democratic Values", in Chicago Journal of International Law, volume 2 number 2, 9-1-2001, http://chicagounbound.uchicago.edu/ cgi/viewcontent.cgi?article=1418\&context=cjil, (accesed 11 January 2017),. P. 389

${ }^{44}$ Kerstin Martens University of Bremen, Germany,, Examining the (Non-)Status of NGOs in International Law, , (accesed 10 January 2017), ps. 1-2. 
not impossible that in the new future, both the corporation in this case Multi National Corporations or Multi National Enterprises will be the subjects of international law,

\section{CONCLUSION}

Originally the only subjects of international law are states. But parallel to development of the international community need that affected by various factors in our life in the world, has been recognized other entities as the subject of international law. These entities has been recognized as such may be based on the historical factors, or may be created by law to fulfill the international community need. Among the subject of international appear in international arena are the Holy See, Knight of the Malta, individuals, International Committee of the Red Cross, International Organizations, insurgent, belligerent and the other subjects of international related to independent sates liked dominion, protectorate and trusteeship states.

The subject of international law development remains running continually. The new development in the subject of international law is the debate on the establishment and recognition of corporations and Non Governmental Organization as subject of international law. The view that corporation and NGO should established as subject of international law is based on the important role those entities has played in international plane. Regardless the important role they play, they can not considered as the subject of international law since the lack recognition from international community.

\section{BIBLIOGRAPHI}

\section{Book}

Bedjaoui, Mohammed (General ed.), (1991) International Law, Achievement and Prospect, UNESCO Paris. Dodrecht/Boston London: Martinus Nijhof Publisher.

Brownlie, Ian, (1979). Principle of Public International Law, third edition. Oxford, Clarendon Press.

Kaczorowsca, Alina, (2002), Public International Law. London: Old Baily Press.

Mochtar Kusumaatmadja and Etty R Agus, (2013), Pengantar Hukum Internasional (Introduction to International Law). Bandung: Alumni, 2013.

Nogoibaeva K. Elida., et.all (ed),(2012), Contemporary International Law, Materials and cases, Biskek, Kyrgyzstan, Printing House “Alty Print” LLC. 


\section{E Book and E Journal}

Bo J Theutenberg, The Holy See, the Order of Malta and International Law, http://www.theutenberg.se/pdf/the holy_see_the_order_of_malta_and_internationa, (acsessed 6 January 2017).

Charnovitz, Steve "Non governmental Organizations And International Law" in The American Journal of International Law, Vol. 100, No. 2 (Apr., 2006), pp. 348-372 Published by: American Society of International Law, http://www.ivr.uzh.ch/dam/jcr:ffffffff-bd54b312-0000-00007162452b/Text-18.pdf (acsessed 10 January 2017).

Iman Prihandono, "Status dan Tanggung Jawab Multi -National Companies (MNCs) dalam Hukum International “, Global \& Strategis, Th. II, No. 1, Januari-Juni 2008, hlm. 69-84, http://journal.unair.ac.id/download-fullpapers-5\%20Status\%20MNC\%20\%20final\%20edit\%200K.pdf, (acsessed 10 January 201).

Kerstin Martens University of Bremen, Germany,, Examining the (Non-)Status of NGOs in International Law, http://www.repository.law.indiana.edu/cgi/viewcontent.cgi? article $=1263 \&$ context=ijgls, (acsessed 10 January 2017).

Mohammad H. Zarei, Azar Safari, The Status of Non-State Actors under the International Rule of Law: A Search for Global Justice, http://www.culturaldiplomacy.org/academy/content/pdf/participant-papers/2014-04lhrs/ Dr_Zarei_and_Azar_Safari_- The Status_of_Non-State_Actors under the _International_Rule_of_Law-_A_Search_for_Global_Justice.pdf, (acsessed 9 January 2017).

Nowrot, Karsten, New Approcah to the International Legal Personality of Multinational Corporations toward a rebutable Presumption of Normative Responsibilities, http://www.esil-sedi.eu/sites/default/files/Nowrot.PDF, (acsessed 9 january 2017).

Wouters, Jan, and Anna-Luise Chané, MULTINATIONAL CORPORATIONS IN INTERNATIONAL LAW, Working Paper No. 129 - December 2013, https://ghum.kuleuven.be/ggs/publications/working_papers/new_series/wp121130/wp129-wouters-chane. pdf (acsessed 6 January 2017)

Samdal, Sunniva, The Issue of legal Personality Within The Modern International Legal System.

https://www.aber.ac.uk/en/media/departmental/lawcriminology/pdf/publications/auslcj 2014/5---The-Issue-of-Legal-Personality-within-the-Modern-International-LegalSystem.pdf, (accessed 9 January 2017).

Shaw, MAlcolm N. International Law, http://jpkc.fudan.edu.cn/picture/article/460/05/ 56/944404884db8857880997b8500b1/694d8cb6-b013-42a3-837a-2298e170ed58.pdf. pdf, (acseesed 16 January 2017).

SLAWOTSKY, JOEL, The Global Corporation As International Law Actor in VIRGINIA JOURNAL OF INTERNATIONAL LAW DIGEST [Vol. 52:79, 2012, http://www.vjil.org/ assets/pdfs/vjilonline2/Slawotsky_Post_Production.pdf (acsessed 9 January 2017).

Thomas, Daniel C. International NGOs, "State Sovereignty, and Democratic Values", in Chicago Journal of International Law, volume 2 number 2, 9-1-2001, http://chicagounbound.uchicago.edu/ cgi/viewcontent.cgi?article=1418\&context=cjil, (acsessed 11 January 2017). 
Working Paper No. 129 - December 2013 MULTINATIONAL CORPORATIONS IN INTERNATIONAL

https://ghum.kuleuven.be/ggs/publications/working_papers/new_series/wp121130/wp129-wouters-chane.pdf (acsessed 6 January 2017). 